\title{
Analisis Unsur Perubahan Sosial Dalam Konteks Uruf Menurut Perspektif Syarak
}

\section{An Analysis of the Elements of Social Change in the Context of 'Urf in Islamic Law}

\author{
Siti Fatimah Salleh (Pengarang Penghubung) \\ Pusat Pengajian Syariah, Fakulti Pengajian Kontemporari Islam \\ Universiti Sultan Zainal Abidin (UniSZA) \\ Kuala Terengganu, Terengganu, Malaysia \\ Tel: +60148181618 E-mel: sitifatimah@unisza.edu.my \\ Siti Khatijah Ismail \\ Pusat Pengajian Syariah, Fakulti Pengajian Kontemporari Islam \\ Universiti Sultan Zainal Abidin (UniSZA) \\ Kuala Terengganu, Terengganu, Malaysia \\ Tel:+60179281267 E-mel: khatijah@unisza.edu.my \\ Zurita Mohd. Yusoff \\ Pusat Pengajian Syariah, Fakulti Pengajian Kontemporari Islam \\ Universiti Sultan Zainal Abidin (UniSZA) \\ Kuala Terengganu, Terengganu, Malaysia \\ Tel: +60139838957 E-mel: zurita@unisza.edu.my
}

\begin{abstract}
Abstrak
Metodologi ijtihad merupakan rukun asas dalam membuat penilaian terhadap penentuan hukum semasa. Salah satu mekanisma yang perlu diambil kira dalam penentuan hukum semasa ialah tentang perubahan sosial. Artikel ini bertujuan untuk melihat konsep perubahan sosial dan terminologi syarak yang sering mempengaruhi perubahan hukum iaitu 'uruf atau dari sudut perkaitannya. Metodologi yang digunakan untuk menghasilkan artikel ini ialah kajian perpustakaan dengan merujuk beberapa kitab utama ilmu usul fiqh dan lain-lain serta karya dalam pengajian sains sosial. Dapatan kajian akan mengenal pasti aspek persamaan atau perbezaan antara dua terminologi iaitu perubahan sosial dan 'uruf melibatkan perubahan sesuatu yang menjadi kebiasaan masyarakat. Aspek perbezaan antara keduanya adalah dalam aspek pengukuran kepada perubahan, iaitu perubahan sosial dianggap berlaku dan masyarakat perlu bertindak mengikut perubahan tersebut. Manakala dalam konteks
\end{abstract}

uruf, masyarakat boleh bertindak mengikut uruf sekiranya perubahan itu diukur oleh syarak sebagai perubahan yang valid untuk diadaptasi.

Kata Kunci: Perubahan sosial; 'uruf; Metodologi ijtihad; Perubahan masyarakat; Perubahan hukum.

\begin{abstract}
Ijtihad (legal reasoning) is a fundamental way of assessing the law and legal dictates in contemporary terms. One of the mechanisms that needs to be considered in determining the law under such terms is the element of social change. This article is intended to look into the notion of social change in relation to 'urf, an Islamic legal term that often impacts on changes in the law. This article employs the literary research technique where relevant classical Islamic works of usul al-fiqh and other secondary social-science materials are consulted. The study will highlight points of differences and similarities between the two
\end{abstract}


notions. A notable difference between the two competing terminologies is in the way 'change' is understood and constructed through each terminology. In social terms, 'change' in bound to take place in society and that society is then expected to adapt according to those changes. On the other hand, in the context of 'urf, society can only adopt cultural changes for as long as such adaptation is permissible and deemed as legally valid.

Keywords: 'Urf; Social change; ijtihad; Legal shifts and adaptation

\section{Pendahuluan}

Dalam menjelaskan beberapa terminologi sama ada dalam bidang sosiologi atau ilmu Islam, perlu dijelaskan asal perkataan sosiologi kerana perkataan perubahan sosial berkait rapat dengan istilah sosiologi. Ini kerana ilmu sosiologi banyak membicarakan tentang kehidupan sosial manusia dan masyarakatnya. Pengasas sosiologi di Barat iaitu Augustus Comte (1798-1857) telah menggabungkan perkataan Latin iaitu sosio dan logos menjadi apa yang dikenali sebagai sosiologi sehingga kini (Mayshil Man,1994) dan (A. Hasan Dawi, 2009). Ada pun dalam peradaban Islam, Ibnu Khaldun (1332-1406) adalah tokoh awal pada abad tersebut yang mengkaji masyarakat sehingga beliau diterima sebagai pelopor dalam bidang ilmu ini. Antara aspek penting yang dikaji ialah berkenaan perubahan dan fenomena sosial (A. Hasan Dawi, 2009). Semenjak kemunculan terminologi ini, sosiologi telah didefinisikan dengan pelbagai cara. Kesemua definisi telah menyebut unsur kaitan aktiviti manusia dan masyarakat. Justeru, definisi sosiologi boleh dirumuskan kepada "ianya adalah merupakan suatu kajian yang sistematik dan saintifik yang mengkaji tentang manusia dan interaksi sosial mereka dalam masyarakat daripada pelbagai sudut" (A. Hasan Dawi, 2009). Implikasi daripada definisi tersebut ia menunjukkan bahawa masyarakat terbentuk apabila terdapat kumpulan-kumpulan manusia yang saling berhubungan antara satu sama lain. Jalinan hubungan manusia inilah yang melahirkan pelbagai fenomena sosial berlaku (A. Hasan Dawi, 2009). Interaksi sosial yang akan menentukan sama ada sesuatu perkara itu akan berkekalan atau pun berubah, sama ada sesuatu itu akan berkembang, ditinggalkan atau pun semakin mundur. Disebabkan bahan kajian sosiologi adalah masyarakat, maka skop kajiannya adalah tersangat luas. Ia bermula di peringkat keluarga sehinggalah peringkat dunia. Justeru, ilmu sosiologi ialah satu bidang ilmu yang mengkaji tentang masyarakat moden manakala ilmu antropologi adalah ilmu yang mengkaji masyarakat primitif atau sebaliknya (belum moden) (A. Hasan Dawi, 2009).

Dalam hal kemasyarakatan, asas kepada pembentukan masyarakat adalah manusia. Beberapa orang manusia yang berinteraksi antara satu sama lain membentuk kumpulan kecil. Kumpulan-kumpulan kecil akan membentuk kumpulan besar seterusnya daripada kumpulan ini akan membentuk kumpulan yang lebih besar dan seterusnya membentuk komuniti. Komuniti boleh dianggap sebagai masyarakat kecil. Gabungan daripada komuniti-komuniti akan melahirkan sebuah masyarakat. Oleh yang demikian, masyarakat hari ini telah didominasi oleh ciri-ciri moden. Pembentukan masyarakat moden melibatkan proses perubahan daripada ciri-ciri masyarakat yang dikatakan lama kepada sesuatu yang dianggap baru. Asas masyarakat iaitu manusia adalah makhluk yang dinamik di mana sering melakukan perubahan. Ini juga bermakna perkembangan tamadun manusia sentiasa mengalami proses perubahan. Maka perubahan telah menjadi ciri masyarakat. Perubahan-perubahan masyarakat moden telah disedari oleh ilmuan sosiologi dan mengkaji perubahan sosial merupakan suatu tradisi dalam bidang sosiologi (A. Hasan Dawi, 2009). Justeru, kemunculan teori-teori sosial adalah lahir daripada hasil kajian fenomena yang berlaku dalam masyarakat (A. Hasan Dawi, 2009). 


\section{Definisi Perubahan Sosial Menurut Bahasa dan Istilah}

Pengertian terminologi perubahan sosial memerlukan penjelasan antara perkataan perubahan dan sosial. Definisi perubahan mengikut bahasa bererti perihal berubah, peralihan atau pertukaran (Kamus Dewan 2007). Perubahan juga didefinisikan sebagai perbezaan antara keadaan semasa dengan sebelumnya (A. Hasan Dawi, 2009) atau perubahan sesuatu dari satu keadaan kepada keadaan lain (Al-Tanubi, 1995). Manakala perkataan sosial menurut bahasa pula bererti segala yang berkaitan dengan masyarakat, perihal masyarakat atau kemasyarakatan (Kamus Dewan 2007). Sosial menurut perspektif istilah membawa erti pergaulan hidup atau hubungan sesama individu (Al-Tanubi, 1995). Ia bererti pergaulan atau hubungan manusia dengan mempertahankan hubungan teratur antara individu dengan individu lain dalam kelompok masyarakat (Sidi Gazalba, 1976,).

Ada pun perubahan sosial menurut istilah ia merujuk kepada beberapa definisi yang diberikan oleh ahli sains sosial seperti terkandung dalam buku Wilbert E. Moore yang mendefinisikan perubahan sosial sebagai perubahan penting dari struktur sosial (Wilbert E. Moore, 1986). Perubahan sosial juga didefinisikan sebagai segala bentuk perubahan institusi sosial dalam satu masyarakat yang akan mempengaruhi sistem sosialnya, termasuk di dalamnya nilainilai, sikap dan pola-pola peri kelakuan di antara kelompok-kelompok dalam masyarakat ('Adli 'Ali Abu, 1997) dan (Rohana Yusof, 2006). Selain itu, ia juga didefinisi sebagai perubahan secara langsung atau terancang dalam sesebuah masyarakat yang mana perubahan itu berlaku dari tahap biasa, berubah kepada tahap yang lebih kompleks selaras dengan objektif dalam sistem sosial. Ia juga diertikan sebagai perubahan yang berlaku dalam struktur masyarakat, perubahan ini yang mengubah sesebuah tamadun dari satu tahap sedia ada kepada tahap tamadun yang cemerlang dan canggih (Ihsan Muhammad alHasan, 1999). Perubahan sosial diertikan sebagai proses berterusan dalam satu tempoh masa yang memberi kesan perbezaan atau pengubahsuaian tertentu dalam sesebuah organisasi atau institusi dalam masyarakat (Al-Tanubi, 1995).

Secara umumnya, suatu perubahan dalam bidang tertentu akan mempengaruhi bidangbidang yang lain dalam sesebuah masyarakat atau institusi sosial lain. Dalam satu kajian berkenaan "Kesan Perubahan Sosial Terhadap Hukum Islam", kajian tersebut mendefinisikan perubahan sosial kepada segala perubahan yang terjadi pada struktur, fungsi, lembaga, pandangan hidup dan perangai manusia dalam masyarakat yang mempengaruhi sistem sosial (Muhammad Firdaus \& Nurul Huda 2002). Sistem sosial juga didefinisi sebagai sistem yang menyusun aktiviti antara gender dan implikasinya terhadap sesuatu hak dan beban tanggungjawab dalam sesebuah masyarakat (Al-'Iwadi t.t.). Penelitian kepada definisi ini ia dilihat mengikut perspektif Islam yang mana ia juga sebagai pencerahan kepada dasar-dasar sistem sosial yang diperkenalkan oleh ahli sosiologi barat iaitu sistem yang sunyi dari etika keagamaan, kecenderungan ukurannya semata-mata kerelevanan.

Dalam menjelaskan definisi perubahan sosial, beberapa aspek penting perlu dijelaskan dalam memahami erti perubahan sosial. Antaranya erti lembaga sosial ialah unsur yang mengatur pergaulan hidup untuk mencapai tata tertib melalui norma (Alpizar, 2008). Lembaga juga membawa erti institusi-institusi seperti institusi kekeluargaan, kehakiman, keselamatan dan sebagainya. Selain itu, konsep sistem yang digunakan dalam definisi tersebut merujuk kepada mana-mana situasi di mana unitnya saling berhubungan untuk masa yang lama secara teratur. Suatu sistem sosial memerlukan unit itu sebagai individu-individu atau sebagai pelaku yang mana interaksinya dipelihara oleh peraturan atau norma (Wilbert E. Moore, 1986).

Perubahan sosial juga dianggap sebagai cara memodifikasikan atau transformasi terhadap susunan sesuatu masyarakat. Ia melibatkan 
perubahan dalam institusi sosial seperti ekonomi, keluarga, perubahan dalam stratifikasi sosial. Perubahan-perubahan besar dalam pola kelakuan masyarakat merupakan asas signifikan terhadap perubahan sosial dan tidak dianggap perubahan sosial apabila berlaku perubahanperubahan kecil dalam kumpulan kecil.

Justeru, perubahan sosial adalah suatu proses yang berlaku berdasarkan satu urutan masa yang melibatkan peranan dan institusi sesuatu sistem sosial. Perubahan yang dimaksudkan boleh disifatkan sebagai ke arah kemunculan kemerosotan atau pertumbuhan sistem sosial berkenaan. Hal ini memberi implikasi kepada perubahan hubungan sosial dan tingkah laku dalam masyarakat. Oleh yang demikian, kelompok masyarakat harus bertindak dalam mengubahsuaikan cara mereka menjalankan aktiviti, hubungan intraksi serta kepercayaan dan nilai perubahan sosial ialah perubahan pada struktur sosial, begitu juga sistem organisasi sosial dalam sesuatu masyarakat itu. Sebagai contoh perubahan bilangan pelajar yang memasuki universiti, perubahan kadar kematian di sesebuah negara dan perubahan pada peranan kaum wanita dalam sesebuah institusi di Malaysia. Perubahan dari segi kehidupan sosial tersebut menunjukkan perubahan dalam struktur sosial dan organisasi sosial, atau ia merupakan sistem sosial yang berkait dengan kehidupan harian iaitu nilai-nilai sosial dan budaya masyarakat. Justeru itu, perubahan sosial dapat dirumuskan sebagai perubahan asas yang terjadi dalam struktur sosial, sistem sosial dan organisasi sosial. Oleh yang demikian, apabila terdapat perubahan ke atas tiga unsur sosial tersebut, ini menunjukkan perubahan sosial telah berlaku (Rohana Yusof, 2006).

\section{Ciri-Ciri dan Faktor Yang Mendominasi Perubahan Sosial}

Dalam menentukan sesebuah masyarakat itu telah melalui perubahan sosial, beberapa aspek penting berkenaan perubahan sosial perlu difahami iaitu sesuatu perubahan yang berlaku tidak semestinya mencerminkan kemajuan sesebuah masyarakat bahkan perubahan sosial boleh dijadikan asas kepada kemunduran sesebuah masyarakat. Selain itu, sifat perubahan yang berlaku melibatkan perubahan besar dalam kelompok masyarakat, ada pun perubahanperubahan kecil dalam masyarakat tidak dikira sebagai perubahan sosial.

Adli Abu (1997) dan Rohana Yusof (2006) menyatakan beberapa ciri-ciri perubahan sosial yang dibincangkan oleh ahli sosiologi seperti berikut:-

\section{Perubahan Sosial Adalah Sejagat Tetapi Bervariasi}

Semua pola sosial adalah bergantung kepada perubahan dari semasa ke semasa sekali pun setiap masyarakat dipengaruhi oleh perubahan sosial tetapi dengan kadar perubahan berlainan. Ahli sosiologi seperti Genhard dan Jean Lenski menyatakan kadar perubahan sosial meningkat dengan kemajuan teknologi masyarakat tersebut. Ini adalah kerana setiap reka cipta dapat berkombinasi dengan pelbagai cara melalui elemen-elemen budaya yang sedia ada. Maka, boleh dikatakan perubahan sosial lebih ketara dalam masyarakat yang mengalami perkembangan pesat dalam teknologi berbanding dengan masyarakat yang kurang kemajuan dalam penggunaan teknologi. Sebagai contoh, kadar perubahan sosial dalam kalangan masyarakat Jepun lebih tinggi berbanding dengan masyarakat Malaysia kerana perkembangan teknologi yang pesat di negara Jepun. Contoh lain tentang perubahan sosial yang memberi implikasi kepada pola tetap seperti pola tetap yang mendorong setiap orang pergi bekerja pada waktu yang sama iaitu di waktu pagi. Pola ini boleh menjadi kurang relevan dengan pertumbuhan bandar di mana kesesakan yang berlaku dimanifestasikan dalam kesesakan lalu lintas dan kemudahankemudahan pengangkutan yang penuh sesak. Kesan perubahan sosial pada pola tetap ini bervariasi ekoran kondisi masyarakat bandar dan luar bandar. 


\section{Perubahan Sosial Adalah Tanpa Dirancang}

Dalam masyarakat industri, perubahan sosial berlaku dengan sengaja atau secara langsung tanpa dirancang. Contohnya, pakar sains berusaha secara berterusan untuk membangunkan teknologi tenaga dan perubahan yang lebih berkesan. Sebaliknya manusia hanya mempunyai sedikit kefahaman tentang kesan perubahan tersebut. Sebagai contoh di Malaysia, peranan automobil memainkan peranan penting dalam perubahan sosial, ia menjimatkan masa pengangkutan dari satu destinasi ke destinasi lain. Kemudahan automobil telah menggalakkan masyarakat bekerja di tempat yang lebih jauh lagi. Selain daripada itu, ia memberi kesan terhadap penubuhan bandar-bandar kecil di merata tempat di Malaysia.

Manakala dalam bidang ekonomi pula, ia menggalakkan pertumbuhan kawasan perindustrian secara berleluasa dan tidak hanya tertumpu pada kawasan yang berdekatan dengan pelabuhan atau lapangan terbang sahaja di negara ini. Justeru, dengan wujudnya teknologi dalam industri automobil telah memberi sumbangan besar ke arah perubahan sosial yang memajukan sesebuah masyarakat.

\section{Perubahan Sosial Adalah Bersifat Kontroversi}

Implikasi daripada perubahan sosial secara langsung akan memaparkan unsur-unsur yang positif dan negatif. Realitinya kebanyakan transformasi sosial akan mendapat sokongan dan bantahan dalam kalangan masyarakat. Contohnya, dalam revolusi industri ia disambut hebat oleh para pemodal. Ini adalah kerana kemajuan teknologi dan kilang-kilang ini akan mendapat keuntungan yang lebih tinggi. Namun, pada masa yang sama kebanyakan pekerja akan gelisah memikirkan masalah kehilangan kerjaya mereka rentetan penggunaan mesin dan robot yang semakin meningkat.

\section{Tempoh dan Kesan Perubahan Sosial Adalah Berbeza}

Terdapat perubahan sosial yang penting berlaku secara berterusan dari satu generasi ke generasi yang lain dan wujud juga perubahan sosial tersebut yang kurang berkesan terhadap masyarakat berlaku dalam tempoh masa yang agak singkat. Sebagai contoh, kemajuan dalam teknologi televisyen dapat menarik perhatian manusia secara berkekalan dan berterusan. Begitu juga revolusi komputer dan automobil yang membawa kesan positif dan negatif dalam jangka masa panjang. Ada pun contoh revolusi mesin taip, kontemporari ini ia sudah lupus dan sudah terlalu jarang digunakan dan ia hanya dilihat penggunaannya di negara-negara yang kurang maju dalam aspek teknologi sahaja. Begitu juga dalam industri penggambaran, penggunaan filem dalam membuat rakaman atau sebarang bahan pembuktian tidak lagi digunakan selepas gelombang kemajuan teknologi digital tersebar luas memenuhi pasaran antarabangsa.

Umumnya, sesuatu penemuan baharu dalam sesebuah masyarakat itu boleh mengakibatkan perubahan pada masyarakat yang bersangkutan. Sesuatu perubahan yang terjadi mempunyai faktor-faktor yang mempengaruhi perubahan sosial dalam masyarakat. Justeru, beberapa faktor yang mempengaruhi perubahan sosial antaranya seperti (Majmu'ah Khubara' 'Arab fi 'Ilmi al-Ijtima,' 2010) (Al-Tanubi, 1995) dan (Rohana Yusof, 2006)

\section{Proses Budaya}

Kebudayaan (Rohana Yusof, 2006,) adalah sebagai satu keseluruhan cara hidup manusia yang meliputi hasil-hasil kehidupan kelompok yang bercorak kebendaan dan bukan kebendaan. Budaya kebendaan merupakan segala ciptaan manusia yang berbentuk objek-objek tertentu seperti alat, bangunan, senjata, kenderaan dan lain-lain lagi. Manakala budaya bukan kebendaan adalah suatu ciptaan manusia yang berbentuk abstrak seperti kepercayaan, adat resam, seni, sikap, undang-undang dan 
sebagainya. Kebudayaan kebendaan terdiri daripada objek-objek fizikal yang direka, dibuat, digunakan dan dikongsi bersama oleh anggota masyarakat. Manakala bentuk atau elemen kebudayaan bukan material seperti ilmu pengetahuan, kepercayaan, sistem kekeluargaan, nilai, undang-undang, peraturan tentang akhlak, sopan santun dan sebagainya.

Kebudayaan mempunyai ciri-cirinya seperti wujud perubahan. Perubahan kebudayaan ialah satu proses di mana aspek-aspek kebudayaan mengalami pengubahsuaian dari semasa ke semasa mengikut keadaan seperti perubahan pemakaian songket tenun tangan kepada tenunan mesin. Antara ciri-ciri lain ialah sesuatu yang dipelajari iaitu segala bentuk tingkah laku, adat resam, bahasa yang dituturi adalah dipelajari bukan dari nalurinya. Sebagai contoh, kanak-kanak akan mempelajari bagaimana mengamalkan adat resam dan nilai-nilai kebudayaan masyarakatnya. Selain itu, elemen budaya ialah dikongsi bersama oleh sekumpulan manusia. Contohnya, bangsa Melayu, Cina, India menggunakan bahasa melayu sebagai bahasa rasmi dan ia merupakan satu simbol yang digunakan oleh anggota masyarakat untuk berinteraksi dan berkomunikasi. Manakala ciri-ciri yang lain juga ialah ianya mempunyai nilai integratif. Contohnya, sesuatu bangsa itu disatupadukan oleh kebudayaan yang sama seperti baju kebangsaan harus berasaskan kepada baju Melayu dan ini merupakan satu nilai integratif yang boleh menggambarkan perpaduan ahlinya.

Justeru, proses budaya merupakan suatu yang dinamik kerana manusia sering memperkenalkan elemen-elemen baru. Begitu juga mereka meninggalkan elemen lain atau mereka cipta sesuatu yang baru serta menyebarkan budaya inovasi kepada orang lain atau masyarakat lain. Proses yang secara terancang atau secara langsung berlaku secara berleluasa akan menyebabkan berlakunya perubahan sosial.

\section{Struktur Sosial}

Junaenah Sulehan (2005) menyatakan sistem sosial merupakan premis asas dalam pembangunan masyarakat.Sistem sosial mengandungi struktur yang terdiri daripada pengelompokan unit-unit, serta institusi-institusi yang didukung oleh pelaku-pelakunya iaitu individu-individu dalam masyarakat. Unit dan institusi ini mempunyai peranan yang menjalinkan fungsi sosial yang berbeza-beza serta kompleks dan adakalanya bercanggah di antara satu sama lain untuk membentuk struktur dan sistem sosial yang berupaya mengekal serta meneruskan kesinambungan sosial dalam sistem berkenaan. Unit dan institusi yang terdapat dalam sistem sosial ini juga ditafsirkan sebagai struktur yang memiliki sifat dan peranan yang berbeza-beza tetapi tidak dapat berfungsi secara terpisah atau tersendiri. Apabila berlaku perubahan dalam unit dan institusi secara langsung ia akan memberi kesan kepada sistem sosial. Unit-unit dalam sistem sosial adalah saling bertindak dan saling terjalin.

Fenomena perubahan dalam masyarakat wujud apabila tindakan ahli komuniti saling mempengaruhi dan dipengaruhi oleh struktur sosial dan institusi serta unit yang sedia wujud dan saling terjalin di antara satu sama lain dari aspek nilai, kepercayaan, norma dan tindakan yang dikongsi bersama. Ini bererti individu dan struktur sosial saling bertindak dalam merancang dan menentukan haluan perubahan.

Sebagai contoh, kewujudan segelintir kelompok elit dalam sistem pemerintahan yang berkuasa dan berautoriti dalam membuat keputusan semasa merancang pembangunan dalam bidang ekonomi atau pun politik, telah berupaya menguasai, mengawal dan menyalurkan pengagihan sumber-sumber yang terbatas. Perancangan yang dibuat dipengaruhi juga oleh faktor sejarah sesebuah negara seperti faktor penjajahan yang telah menyebabkan pemusatan kuasa dan kawalan dalam kalangan segelintir kelas sosial dalam sektor atau bidang tertentu sehingga sumber-sumber pengeluaran 
dalam pembangunan hanya dukuasai oleh segelintir kelompok sosial sahaja. Pencerahan kepada realiti tersebut seperti revolusi hijau merupakan satu contoh klasik dalam pengajian pembangunan di mana perubahan daripada pertanian yang bercirikan sara diri kepada pengeluaran yang bersifat komersial telah berlaku di negara-negara membangun. Dalam megubah bentuk pembangunan pertanian tradisional kepada pengeluaran pertanian komersial, ini memerlukan pengkhususan dalam tanaman yang boleh menghasilkan keuntungan tinggi dengan penggunaan buruh dibayar serta mekanisasi tinggi. Alat-alat peralatan pengeluaran pertanian yang menggunakan tenaga haiwan dan manusia diambil alih oleh mesin, jentera serta peralatan yang lebih baik dan cekap. Kehebatan revolusi pertanian yang berlaku ini telah mencetuskan perubahan sosial akibat pengeluaran lebihan makanan yang boleh dieksport, teknik pengeluaran yang menjimatkan kos buruh, penggunaan mesin-mesin baru, benih dan baka yang bermutu baik serta penggunaan racun dan baja.

Perubahan dalam sistem pengeluaran komersial membentuk struktur sosial yang berasaskan hubungan formal dan sistematik.Selain revolusi pertanian, pertumbuhan dan pembangunan sektor perindustrian, perusahaan dan perdagangan turut memberikan kesan terhadap sistem sosial masyarakat yang menyebabkan peranan dan fungsi sosial menjadi lebih kompleks serta saling lengkap melengkapi hasil daripada mobiliti sosial yang semakin baik.

Kesimpulannya, struktur sistem sosial memainkan peranan penting dalam mencetus perubahan serta pembangunan dalam sistem masyarakat.Struktur sistem sosial tersebut termasuklah sistem kepemimpinan, perundangan, ekonomi, pendidikan, kesihatan, nilai budaya, kepercayaan dan adat resam.

\section{Idea}

Idea merupakan satu inovasi yang mengubah pandangan orang dalam sesebuah masyarakat, seperti juga dengan perubahan teknologi. Idea-idea baru berupaya mempengaruhi cara kehidupan manusia. Sebilangan besar ahli sosiologi berpendapat idea bukan sahaja dapat mempengaruhi kebudayaan material tetapi juga idea-idea lain. Sekiranya idea-idea baru yang berkaitan dengan bidang-bidang seperti agama, ekonomi, pendidikan atau politik dilaksanakan akan memberi kesan terhadap perubahan sosial (Rohana Yusof, 2006).

\section{Persekitaran Semula Jadi}

Masyarakat manusia dan persekitaran semulajadi adalah saling berhubungan antara satu sama lain. Oleh itu salah satu daripada kedua-dua elemen ini berubah akan menyebabkan perubahan sosial akan berlaku dan mempengaruhi salah satu elemen lagi. Sebagai contoh, perubahan persekitaran semula jadi seperti gempa bumi akan memberi kesan jangka panjang dan pendek. Tetapi bukan semua persekitaran membawa kepada perubahan sosial.Ia hanya melibatkan kawasan-kawasan yang sering dilanda malapetaka seperti banjir, kemarau, gempa bumi atau gunung berapi. Ia mungkin berlaku perubahan kerana penduduknya terpaksa berpindah ke kawasan lain yang akan membentuk hubungan sosial dengan masyarakat lain pula. Situasi beginilah yang membawa kepada perubahan sosial kerana berlaku perubahan pada persekitaran semulajadi.

\section{Demografi}

Faktor demografi ini mencakupi jumlah atau peratusan kelahiran, kematian, nisbah gender, purata bilangan penduduk di pendalaman dan yang berhijrah ke bandar dan lain-lain., kesemua ini berperanan dalam mencetuskan perubahan sosial dalam sesebuah masyarakat (Al-Tanubi, 1995). Perubahan dalam aspek saiz dan komposisi penduduk juga merupakan faktor kepada perubahan sosial. Pertambahan penduduk yang pesat di sesebuah negara mungkin akan menyebabkan penduduknya tidak mempunyai makanan yang mencukupi atau menghadapi kebuluran sebagaimana yang 
berlaku di Afrika dan India.

Penduduk dari kawasan yang sesak atau kampung akan berhijrah ke tempat-tempat lain yang mana proses tersebut akan memberi kesan kepada struktur sosial. Sebagai contoh, penghijrahan warga desa ke bandar seperti Kuala Lumpur menyebabkan terdapat banyak kawasan setinggan. Begitu juga keadaannya bagi negara yang terdapat ramai penduduk warga tua akan menghadapi masalah penjagaan orang-orang tua. Sebaliknya jika kadar kelahiran menurun, maka akan terdapat hospital bersalin dan sekolah ditutup. Perubahan-perubahan yang seumpama ini merupakan faktor utama kepada perubahan sosial.

\section{Kepimpinan}

Pemimpin-pemimpin yang berkaliber dan mempunyai banyak idea boleh membawa kepada perubahan sosial apabila mereka mempunyai pengaruh yang boleh mempercayai falsafah mereka. Namun perubahan kerana pengaruh pemimpin kebiasaannya tidak berterusan kerana sesuatu pergerakan sosial itu akan tamat dengan kematiannya pemimpin tersebut atau tamat tempoh kekuasaannya.

\section{Inovasi Dalam Bidang Teknologi}

Kemajuan dalam bidang teknologi juga merupakan faktor utama yang menyumbang kepada perubahan sosial. Teknologi boleh didefinisikan sebagai aktiviti atau kajian yang menggunakan pengetahuan sains untuk tujuan praktis dalam industri, pertanian, perubatan, perniagaan dan lain-lain.-

Sebelum kemajuan teknologi, manusia menggunakan alat-alat pengangkutan yang mundur untuk bergerak dari satu tempat ke tempat lain. Alat-alat pengangkutan yang seumpama ini mengambil masa yang lama dan memerlukan pengorbanan tenaga dalam sesuatu perjalanan. Selain itu dalam aspek keselamatan juga terdedah kepada ancaman-ancaman yang berisiko kepada maruah dan diri khususnya bagi kaum wanita. Sebagai contoh alat-alat pengangkutan terdahulu seperti rakit, perahu, sampan dan di negara padang pasir menjadikan haiwan seperti himar, kuda, unta sebagai alat tunggangan dan alternatif pengangkutan mereka dalam proses interaksi sosial sesama mereka.

Namun, inovasi yang berlaku dalam bidang teknologi pengangkutan memberi kesan yang mendalam dalam masyarakat. Sebagai contoh, penciptaan teknologi motor bot telah mempercepatkan perjalan diperairan sekaligus menjimatkan masa dan tenaga pengguna. Manakala kemajuan teknologi yang mencipta kereta telah membolehkan manusia lebih mudah untuk bergerak dari satu lokasi ke lokasi yang lain, begitu juga dengan kemunculan pengangkutan diudara seperti kapal terbang memudahkan seseorang melakukan perjalanan dari satu destinasi ke destinasi yang lain. Implikasi dalam kemajuan teknologi kenderaan di perairan, di darat dan di udara boleh merapatkan jarak antara kampung dengan bandar sekaligus antara negara-negara di merata dunia. Selain itu, ia juga memajukan kegiatan ekonomi di kawasan luar bandar. Walau bagaimana pun tidak dapat dinafikan bahawa kesan negatif sampingan seperti pencemaran udara dan kesesakan lalu lintas di bandar-bandar tidak dapat dielakkan akibat daripada inovasi teknologi ini.

Kemajuan teknologi dalam bidang pertanian seperti penyelidikan padi yang boleh memberi hasil padi dalam masa yang lebih singkat. Teknologi pengeringan dan pengilangan dapat mempercepatkan lagi proses pengeluaran padi. Justeru, melalui teknologi pertanian, manusia dapat menambahkan hasil pertanian untuk memenuhi keperluan sendiri serta mengeksport ke negara lain. Manakala dalam teknologi pembuatan, peralatan yang serba canggih dan automatik telah meningkatkan produktiviti sesebuah negara dan secara langsung meningkatkan lagi aktiviti pembangunan ekonomi dalam sesebuah negara. 


\section{Ketetapan Undang-Undang}

Ketetapan undang-undang, akta, qarar, enakmen, statut, prosedur dan lain-lain dalam sesebuah negara atau sesebuah institusi dan lain-lain juga memberi implikasi kepada suasana kehidupan sosial. Kedudukan undang-undang sedia ada membezakan status perubahan sosial antara sesebuah negara. Namun, jika berlaku perubahan atau penggubalan baru dalam sesebuah akta, ia akan mempengaruhi suasana kehidupan sosial dari keadaan sebelumnya kepada keadaan yang baru. Undang-undang yang dimaksudkan ini antaranya seperti undang-undang dalam perindustrian, pertanian, kesihatan, pemasaran, percukaian, eksport import, penempatan dan sebagainya yang mencetus kepada perubahan sosial dalam sesebuah negara (Al-Tanubi, 1995).

\section{Definisi 'Uruf}

Perbincangan tentang konsep perubahan sosial berserta faktor dan ciri-cirinya telah dinyatakan di awal karya ini. Dalam mengemukakan perkaitan antara dua terminologi ini, penjelasan tentang 'uruf perlu dinyatakan bagi merealisasikan ruang persamaan dan berbezaan tersebut.

Dalam metodologi penentuan hukum fiqh semasa, 'uruf merupakan satu mekanisma penting yang berfungsi sebagai penafsir kepada situasi sosial yang berlaku sebelum sesuatu hukum itu diputus dan difatwakan. 'Uruf didefinisikan sebagai sesuatu perkara yang menjadi kebiasaan manusia sama ada dalam bentuk perkataan dan tingkahlaku (Al-Durayni, 1997; Shalabi, 1986; Al-Zuhayli, 2004; Ibnu 'Abidin t.t.).

\section{Syarat-Syarat 'Uruf}

Dalam memastikan sesuatu perkataan atau tingkah laku itu sebagai ' $u r u f$, perlu dinyatakan beberapa syarat yang perlu diambil kira dalam penelitian hukum ' uruf. Syarat-syaratnya adalah sebagaimana berikut (Al-Zuhayli, 2004; AlZarqa', 1998 Shalabi, 1986; Al-Ashqar, 2012):

\section{Berterusan}

'Uruf mestilah berlaku secara berterusan dan menyeluruh dalam sesebuah tempat, puak, kaum atau sesebuah negara. Sebagai contoh, menjadi amalan tradisi masyarakat Arab di Mesir untuk melengkapi sesebuah ikatan perkahwinan tentang kos penyediaan perabot kelengkapan rumah bagi bakal suami isteri adalah ditanggung oleh pihak bakal pengantin perempuan. Situasi ini berbeza 'urufnya dengan masyarakat di Jordan iaitu kos penyediaan perabut ditanggung sepenuhnya oleh bakal suami.

Manakala situasi yang berbeza tentang 'uruf masyarakat Arab dengan 'uruf masyarakat Islam Melayu yang tidak mengambil pendekatan masyarakat Arab dalam pelaksanaan amalan pemberian mahar iaitu mahar (ta'jil). Pemberian ini ditangguh sebahagian dari keseluruhan mahar iaitu dengan sebahagian pertama diberi semasa akad perkahwinan manakala sebahagian lagi diberi selepas akad perkahwinan yang kebiasaannya diberikan dalam jangka masa panjang tanpa ditentukan bila masa pemberian sebahagiannya lagi. 'Uruf masyarakat Melayu Islam kebiasaannya melaksanakan pemberian mahar sepenuhnya semasa akad perkahwinan.

\section{'Uruf Mestilah Wujud Ketika Pelaksanaan Sesuatu Perkara}

Kewujudan 'uruf semasa pelaksanaan sesuatu perkara atau hukum mesti merujuk kepada 'uruf yang lalu iaitu 'uruf semasa memutuskan hukum. Jika ia dirujuk kepada ' $u r u f$ selepas atau sebelum proses tersebut, ia tidak diambil kira. Sebagai contoh 'uruf dalam pelaksanaan bai" wafa', masyarakat dahulu mengamalkan konsep ijab qabul dalam akad jual beli. Kontemporari ini pengaplikasian tersebut tidak lagi digunakan ekoran perubahan sosial hidup manusia yang telah merubah 'uruf masyarakat melalui proses inovasi dalam teknologi telah merubah konsep amalan sebelumnya. Sebagai contoh akad jual beli sesuatu melalui mesin elektronik atau belian melalui internet. Dalam keadaan ini konsep akad jual beli tidak dapat diaplikasikan lagi ekoran 
perubahan sosial yang berlaku.

Tidak Bercanggah Dengan Keputusan Antara Pihak Yang Terlibat Dalam Sesuatu Kontrak

Dalam situasi ini, 'uruf tidak diambil kira apabila berlawanan dengan keputusan yang dicapai antara kedua pihak.Justeru, keputusan tersebut perlu didahulukan daripada mengambil kira faktor 'uruf. Sebagai contoh, menjadi kebiasaan dalam masyarakat Malaysia atau 'uruf dalam perkahwinan kedua-duan pihak pengantin menyediakan barang hadiah sebagai hantaran dihari majlis perkahwinan.Aktiviti pemberian hantaran sudah sebati dalam jiwa masyarakat Melayu. Namun, jika antara kedua pihak pengantin ini bersetuju dan sepakat untuk tidak membawa hantaran tersebut. Keputusan itu yang dilaksanakan iaitu majlis perkahwinan tanpa dulang hantaran, bukan apa yang menjadi kebiasaan pada majlis perka hwinan. Dalam situasi ini 'uruf tidak boleh memainkan peranan kerana persetujuan yang disepakati antara pengakad dan penerima akad lebih kuat daripada ' $u r u f$. Ini diperkukuhkan oleh kaedah fiqh (Al-Zuhayli 1999, 304): المعروف عرفاً (كالمشروط شر عا".

\section{Uruf Mestilah Tidak Bercanggah Dengan Nas Syarak}

Sesuatu 'uruf yang berlaku mestilah selari dengan peraturan syarak yang terkandung di dalam al-Quran dan al-Sunnah. Dalam erti kata lain mana-mana hal yang dikira 'uruf tidak boleh bercanggah dengan nas al-Quran dan al-Hadis atau bercanggah dengan prinsip asas dalam shariah. Contohnya dalam sesuatu akad mesti ada persetujuan antara kedua-dua pihak.Justeru sekiranya wujud 'uruf yang bercanggah dengan konsep persetujuan itu, maka 'uruf tersebut tidak perlu diambil kira. Begitu juga keadaannya apabila 'uruf bertentangan dengan nas secara terus ' $u r u f$ tersebut tidak perlu dijadikan asas dalam penentuan hukum kerana ia adalah ' $u r u f$ fasid. 'Uruf fasid (Al-Durayni,1997) ialah 'uruf yang batil pada asal 'uruf itu kerana ia bercanggah dengan nas yang khusus atau asas-asas syarak serta disiplin syariah yang tidak menerima ketentuan manusia merubah syarak. Ia meliputi amalan yang menghalalkan perkara haram antaranya seperti meminum arak yang mana perbuatan tersebut telah dinyatakan oleh nas secara khusus. Begitu juga tindakan menggugurkan perkara wajib seperti amalan meninggalkan solat ketika musibah.

\section{Nas Al-Quran Yang Berkait Dengan 'Uruf}

Perkaitan 'uruf atau kebiasaan masyarakat dalam penentuan hukum syarak mempunyai implikasi yang mendorong seseorang mujtahid mengenal pasti aspek perubahan dalam 'uruf agar pemfatwaan hukum selaras dengan perinsip agama yang menekankan kemaslahatan dan menolak kefasadan. Dalam metodologi ijtihad juga ditemukan bukti-bukti adanya hubungan antara hukum syarak dengan 'uruf. Antara dalil-dalil yang memperakui kedudukan 'uruf dalam penentuan hukum ialah seperti berikut: Firman Allah (s.w.t.) iaitu:

Terjemahan: ...dan bergaulah kamu dengan mereka (isteri-isteri kamu itu) dengan cara yang baik (Quran, 4 19).

Begitu juga firman-Nya tentang dalil 'uruf iaitu berkenaan kafarah melanggar sumpah:

Terjemahan: ...maka bayaran dendanya ialah memberi makan sepuluh orang miskin dari jenis makanan yang sederhana yang kamu (biasa) berikan kepada keluarga kamu....(Quran, 5 89).

Firman Allah (s.w.t.) berkenaan suruhan pelaksanaan nafkah kepada isteri dan anakanak, ianya disebut dalam ayat 233 dari surah al-Baqarah iaitu: Terjemahan: ...dan kewajipan bapa pula ialah memberi makan dan pakaian kepada ibu itu menurut cara yang sepatutnya (Quran, 2 233).

Implikasi pelaksanaan hukum daripada nas tersebut ialah hukum syarak tidak dapat dilaksanakan tanpa merujuk kepada realiti 
sebenar yang berlaku dalam individu dan masyarakat atau 'uruf semasa di saat pelaksanaan hukumnya.

\section{Interpretasi Perkaitan Antara Terminologi Perubahan Sosial Dan 'Uruf}

\section{Penglibatan Masyarakat}

Sesuatu perubahan sosial akan berlaku apabila wujud perubahan besar secara menyeluruh dalam kelompok masyarakat, seperti berlaku proses inovasi dalam bidang teknologi yang menyebabkan penggunaan pengangkutan dengan menggunakan tenaga haiwan serta perahu sudah semakin pupus dan hampir tidak digunakan. Inovasi ini telah merubah masyarakat kepada penggunaan pengangkutan seperti motor, kereta, van, bas, komuter, kapal terbang, jet dan sebagainya. Dalam konteks 'uruf, perubahan yang disebabkan inovasi teknologi pengangkutan ianya harus kerana menepati perinsip syarak iaitu memudahkan urusan interaksi sesama manusia.

'Uruf juga mengambil kira aspek perubahan besar dalam kelompok masyarakat seperti dalam masalah upah mu'adhdhin (tukang azan), imam, khatib, pengajar ilmu agama, pengajar al-Quran iaitu pada asasnya mereka tidak harus mengambil bayaran sebagaimana diputuskan oleh Abu Hanifah, Abu Yusuf dan Muhammad kerana urusan tersebut merupakan perkara ketaatan seperti tidak harus mengambil bayaran dan menyewa individu lain dalam melakukan ibadah puasa, solat, membaca al-Quran dan sebagainya (Ibnu 'Abidin t.th; Al-Zarqa' 1998). Namun, realiti hari ini disebabkan perubahan masa dan kekangan individu dalam melakukan kebajikan tersebut. Fuqaha kebelakangan ini menfatwakan dibolehkan mu'adhdhin mengambil upah untuk berbuat demikian (Ibnu 'Abidin t.t.; Al-Zarqa', 1998; Shalabi, 1986). Begitu juga keadaannya pengajar-pengajar ilmu agama. Perubahan ini berlaku kerana individu terdahulu yang melakukan kebajikan ini mendapat bantuan dari Baitulmal secara berterusan yang mana mereka tidak berhajat kepada bayaran upah (Al-Zuhayli, 2009). Ironinya, bayaran upah seumpama ini tidak lagi wujud dewasa ini menyebabkan mereka harus mengambil upah kerana tanpa tindakan seumpama itu boleh menyebabkan sukarelawan tersebut mengundurkan diri kerana tiada punca pendapatan. Keadaan ini akan memberi impak negatif dalam pembangunan modal insan generasi al-Qurani dan modal insan yang bertaqwa, utuh pada agama. Perubahan ' $u r u f$ dalam aspek ini mempunyai persamaan iaitu melibatkan sekumpulan masyarakat. Ironinya, keadaan berbeza dengan 'uruf yang mana dalam situasi tertentu hanya melibatkan individu yang bersifat keseorangan seperti yang berlaku kepada Ibnu 'Abbas apabila datang seorang pembunuh meminta fatwa tentang taubatnya. Hadis Ibnu 'Abbas ini ialah:

Ibnu 'Abbas menjawab dengan tegas: "Taubat orang yang melakukan jenayah pembunuhan itu tidak diterima oleh Allah (s.w.t.)" (A1-“Asqalani 1995, no. Hadis 2574, Jil. 4: 343). Fatwa ini bukan bererti beliau tidak memahami firman Allah (s.w.t) sebagaimana berikut:

Terjemahan: Katakanlah (wahai Muhammad): "Wahai hamba-hambaKu yang telah melampaui batas terhadap diri mereka sendiri (dengan perbuatan-perbuatan maksiat), janganlah kamu berputus asa dari rahmat Allah, kerana sesungguhnya Allah mengampunkan segala dosa..." (Quran, 39 53).

Ayat yang dinyatakan itu menjelaskan bahawa Allah (s.w.t.) mengampun segala dosa kecuali dosa syirik dengan syarat penjenayah tersebut benar-benar bertaubat. Oleh yang demikian, jika diperhatikan kisah ini menunjukkan bahawa Ibnu 'Abbas mengeluarkan fatwa yang agak jauh dari konteks makna ayat tersebut. Namun untuk mencapai kehendak maqasid dan maslahah beliau memfatwa taubat pembunuh tidak diterima kerana melihat kepada 'uruf orang yang bertanya terdapat padanya tanda-tanda kemarahan dan keinginan untuk membunuh. Justeru, pertanyaan lelaki itu mempunyai maksud tersirat iaitu jika perbuatan membunuh 
itu diampuni, maka dia akan meneruskan perbuatan membunuh.

Dalam situasi begini, pengeluaran fatwa oleh mufti bukan sahaja bersandarkan pada nas-nas syarak tetapi ia perlu disandarkan juga pada elemen maqasid al-Shar'iyyah dan keadaan semasa seperti yang dizahirkan oleh adat kebiasaan sama ada di peringkat individu atau perseorangan atau pun dalam masyarakat.

\section{Norma Sosial}

Norma ialah ukuran untuk menentukan sesuatu yang mana ia bergantung sepenuhnya kepada tingkah laku manusia. Ia juga merupakan peraturan atau ketentuan yang sudah menjadi kebiasaan yang dijangka akan dipatuhi oleh setiap anggota masyarakat (Kamus Dewan, 2007). Kelakuan dan tindakan anggota masyarakat ditentukan oleh norma masyarakat yang dianggap wajar dalam sesuatu masyarakat.

Manakala dalam 'uruf kerelevanan sesuatu kelakuan dan keupayaan bertindak diukur oleh syarak yang mana tidak semua aktiviti sosial diiktiraf oleh syarak seperti pergaulan bebas antara lelaki dan wanita. Justeru ia berbeza dengan norma sosial yang mana norma tersebut dinilai mengikut kewajaran hasil daripada tindakan anggota masyarakat.

\section{Faktor-Faktor Yang Membawa Kepada Perubahan}

Sesuatu perubahan sosial yang berlaku disebabkan wujudnya faktor penolak iaitu faktor-faktor yang membawa kepada perubahan sosial seperti proses budaya, struktur sosial, idea, persekitaran semula jadi, penduduk, kepimpinan dan inovasi dalam bidang teknologi.

Ada pun dalam 'uruf, aspek-aspek yang membawa kepada perubahan 'uruf ialah sebagaimana yang dinyatakan oleh Ibnu alQayyim adalah disebabkan perubahan masa, tempat, keadaan dan kebiasaan manusia atau ahlinya. Menurut Ibnu 'Abidin al-Hanafi, beliau menjelaskan lagi faktor-faktor perubahan ' $u r u f$ ialah kerana berlaku keperluan atau kefasadan manusia pada sesuatu zaman. Faktor-faktor inilah memberi implikasi kepada perubahan hukum syarak yang didasari oleh 'uruf dan pengekalan hukum dalam situasi ini akan membawa kepada kesukaran, kemudharatan dalam kalangan manusia serta bercanggah dengan perinsip syarak iaitu meringan dan mempermudahkan serta menangani kemudharatan dan kefasadan (Shalabi, 1986).

Faktor-faktor perubahan 'uruf antaranya adalah kerana peredaran zaman atau era, masa dan waktu. Ketiga-tiga terminologi ini mempunyai perkaitan antara satu sama lain. Pengaruh perubahan zaman memberi implikasi kepada corak dan gaya hidup masyarakat yang mengundang kepada perubahan sesuatu hukum syarak daripada sebelumnya kepada hukum semasa (Al-Qardawi, 2008). Sebagai contoh pendirian Sayyidina 'Umar al-Khattab tentang asnaf mu'allaf. Berpandukan kepada kronologi pemberian zakat kepada golongan ini, pada zaman Rasulullah (s.a.w) pemberian zakat ini berlangsung secara aktif dengan hasrat pemberian ini mereka tidak memusuhi Islam dan ia juga sebagai pendekatan dakwah kepada ajaran Islam. Ini berdasarkan pengakuan Safwan bin Umayyah, beliau mengatakan: "Rasulullah memberikanku sejumlah harta, pada hal Dia adalah orang yang paling aku benci. Oleh kerana Dia selalu memberikanku harta tersebut, maka jadilah dia orang yang paling aku cintai," (Muhammad Baltaji, 2007; Al-Sabuni, t.th.; Al-Jasas, 1994). Allah (s.w.t.) juga telah menetapkan asnaf ini dalam firmanNya iaitu:

Terjemahan: "Sesungguhnya zakat-zakat itu, hanyalah untuk orang-orang fakir, orang-orang miskin, pengurus-pengurus zakat, para mu'allaf yang dipujuk hatinya, untuk (memerdekakan) hamba, orang-orang yang berhutang, untuk jalan Allah dan untuk mereka yang sedang dalam perjalanan..." (Quran, 9 60).

Melalui nas ini, pemberian zakat kepada 
golongan mu'allaf ini disebut secara jelas dalam ayat tersebut sebagai golongan yang layak menerima zakat. Namun, pendirian 'Umar (r.a) yang menyekat pemberian ini kepada asnaf al-Mu'allaf telah mendapat kritikan dan perbincangan serius dalam kalangan fuqaha dan mujtahid sehingga ada yang mengatakan tindakan 'Umar (r.a) itu menasakhkan hukum dalam al-Quran (Al-Sa'di, 2003). Ini berikutan tindakan 'Umar yang menafikan zakat pada zaman pemerintahan Abu Bakr (Ibn al-Humam, 2003; Muhammad Baltaji, 2007; al-Jasas, 1994) dengan hujjahnya: "Dahulu Rasulullah menganggap kalian sebagai mu'allaf, ketika Islam saat itu di ambang pengenalan dan pengikutnya hanya sebilangan masyarakat sahaja.Tetapi Allah s.w.t. menjadikan kedudukan Islam sudah diterima dan tersebar luas dengan gemilang (Al-Qurtubi, 2010; al-Jasas, 1994), maka pergilah kalian bekerja sebagaimana kaum muslimin bekerja. Kebenaran adalah berasal dari Tuhan kalian. Barang siapa yang mahu beriman, maka berimanlah dan barang siapa yang tidak mahu beriman maka kufurlah" (alJassas, 1994).

Rentetan daripada tindakan 'Umar ini, tidak diragukan lagi bahawa hukum pemakaian agihan zakat kepada golongan mu'allaf ini bergantung kepada kesesuaian situasi dan kedudukan yang ada dalam masyarakat muslim. Keputusan ini bukan bererti 'Umar dan Abu Bakr yang menyokong tindakan khalifah itu mengenepikan nas al-Quran atau menasakhkannya tetapi beliau bertindak sebagai memberhentikan (tawaqquf) pemberian zakat kepada golongan ini kerana objektif pensyariatan hukum tersebut sudah dicapai. Ini dikuatkan dengan kata-kata Ibnu Hummam yang merumuskan permasalahan tersebut iaitu: tujuan akhir dari tashri' ini adalah demi tercapainya kemenangan dan kejayaan kaum muslimin. Sedangkan pemberian harta kepada orang-orang mu'allaf pada zaman Rasulullah, hanyalah sebagai premis minoritinya untuk menambah kekuatan Islam (Ibn al-Humam, 2003). Apabila matlamat kemenangan Islam mampu dicapai dan diraih ia tidak perlu kembali kepada strategi awal yang akan menunjukkan Islam dan orangorang Islam masih dalam keadaan lemah. Tindakan berterusan kepada strategi awal akan menyebabkan tindakan yang berlawanan arus kegemilangan Islam yang telah dicapai pada zaman Rasulullah (s.a.w) dengan penubuhan Kota Madinah.

Begitu juga dengan peralihan dan peredaran masa telah merancakkan lagi kemajuan dalam sains teknologi yang telah memonopoli sebahagian besar unsur-unsur perubahan sosial. Keadaan ini telah menyaksikan perubahan dan penilaian semula pada sebahagian hukum syarak oleh mujtahid kontemporari. Pengaplikasian terus hukum-hukum silam yang berkait dengan isu-isu kontemporari tidak lagi rasional kerana ia memperlihatkan hukum Islam sebagai lesu, songsang dan jumud. Dalam pada masa yang sama isu-isu kontemporari juga sering muncul dan terbit ekoran peredaran masa yang menuntut para mujtahid memerah minda berijtihad melalui mekanisma qias dan sebagainya kerana isu-isu ini tidak pernah timbul pada zaman silam.

Faktor perubahan ' uruf juga adalah disebabkan faktor tempat atau "al-makan”. Beberapa kaedah fiqh menyebut tempat merupakan faktor kepada perubahan kehidupan sosial masyarakat. Perubahan dan perbezaan kepada tempat sememangnya memberi implikasi signifikan kepada perubahan sesuatu hukum syarak.

Perbezaan hukum yang melibatkan tempat di Kota Mekkah dan Madinah telah diklasifikasikan oleh syarak sebagai al-Haram (Al-Sayyid Sabiq, 1999). Perbezaan tempat telah menunjukkan perbezaan hukum syarak yang diaplikasikan berbanding dengan kawasan atau tempat lain. Contohnya ialah di kawasan al-haram tidak dibenarkan berlaku pertumpahan darah sama ada pembunuhan atau peperangan memotong pokok dan tumbuhan tanpa sebab tertentu (Al-Farra', 2006; Al-Sayyid Sabiq, 1999). Ini dibuktikan melalui sabda baginda SAW iaitu, Terjemahan: Daripada Anas bin Malik (r.a):

"Sesungguhnya Rasulullah (s.a.w) memerhati 
dari bukit Uhud, Baginda berkata: bukit ini menyayangi kita dan kita menyayanginya. Ya Allah! Sesungguhnya Ibrahim telah mengharamkan Mekah dan sesungguhnya aku mengharamkan (kawasan) antara dua La Batayiaitu antara dua bukit-". (Al-Bukhari 2000, no. Hadis 7333, 2000, 141-142).

Orang-orang kafir dan musyrik juga tidak dibenarkan mendiami kedua-dua tempat ini, dilarang membunuh haiwan jinak dan tidak boleh melepasi kawasan al-haram kecuali dengan berihram (Al-Mawardi,1996).

Penentuan hukum juga berbeza implikasinya ekoran perbezaan al-makan atau tempat seperti perbezaan iklim bagi negara yang bermusim sejuk dan panas. Perbezaan iklim ini mempengaruhi penetapan hukum yang melibatkan tempoh panjang dan pendek di waktu malam dan siang. Kesan perbezaan tempoh ini membabitkan hukum-hukum fiqh seperti penetapan waktu solat dan waktu sahur serta berbuka bagi ibadah puasa. Selain perbezaan antara dua musim ini, ia juga berbeza dalam aspek penentuan hukum bagi negara-negara yang tidak bermusim.

Begitu juga unsur perbezaan tempat perlu diraikan dalam penentuan hukum bagi negaranegara yang mengalami hujan lebat serta musim sejuk bersalji tebal, situasi ini menyukar dan merumitkan penduduknya keluar rumah bagi menunaikan kewajipan solat jamaah di masjid bagi pandangan yang mengatakan solat jamaah itu wajib dan sunat solat jamaah bagi mereka yang mengatakan ianya sunat. Tuntutan solat jamaah di masjid menjadi gugur bagi masyarakat yang hidup di tempat atau negara bermusim sejuk dengan berada pada paras suhu kesejukan melampau. Dalam keadaan ini juga ulama mengharuskan golongan ini bertayammun menggantukan wudhuk bagi mereka yang alahan dengan kesejukan melampau ini dan tiada keupayaan memanaskan air untuk berwuduk. Golongan yang mengalami hujan lebat dan sukar untuk keluar rumah juga dibenarkan jamak solat akibat kesukaran hujan lebat.
Situasi ini berlaku kepada 'Amru bin al-'As dalam satu rombongan musafir beliau dalam keadaan berjunub. 'Amru bin al-'As menunaikan solathanya dengan tayammum. Apabila pulang beliau mengadu kepada Nabi (s.a.w) dengan memberitahu baginda pada malam tersebut di tempat yang beliau bermusafir itu mengalami kesejukan melampau dan 'Amru bin al-'As membaca ayat ini kepada baginda (s.a.w):

Terjemahan: ...dan janganlah kamu berbunuhbunuhan sesama sendiri. Sesungguhnya Allah sentiasa Mengasihani kamu (Quran, 4 29).

Selepas baginda (s.a.w) mendengar rintihan sahabatnya, baginda tersenyum sebagai tanda taqrir atau pengakuan dan pengiktirafan baginda SAW kepada tindakan sahabatnya (Al-Qardawi, 2008).

Instrumen-instrumen seperti yang dinyatakan itu perlu diambil kira dalam proses perubahan hukum syarak. Justeru dalam hal ini, faktorfaktor perubahan sosial yang dinyatakan oleh ahli sosiologi disebut secara terperinci. Manakala faktor perubahan 'uruf dinyatakan oleh ulama usul secara general yang mampu ditakwil secara terperinci oleh para mujtahid.

\section{Individu Pendesak}

Individu atau anggota masyarakat merupakan mekanisma pendesak secara konsensus. Dalam hal ini manusia bebas dalam mencetuskan perubahan masyarakat menurut perspektif ilmu sosiologi dan ilmu Islam iaitu 'uruf. Semua individu atau anggota masyarakat mempunyai peranannya dalam perubahan tersebut.Jika dalam 'uruf ianya tidak dihadkan kepada mujtahid sahaja bahkan semua manusia mempunyai komitmen dalam perubahn uruf dan perubahan sosial. Dalam hal ini kedua-dua terminologi mempunyai persamaan dalam aspek individu penolak.

\section{Paksi Penentu Kepada Perubahan}

Dalam perubahan sosial, paksi penentu kepada 
tingkah laku masyarakat ditentu oleh norma yang dinilai mengikut kewajaran hasil tindakan anggota masyarakat yang didasari oleh akal semata-mata. Ini berbeza keadaannya dengan 'uruf, aktiviti atau tingkah laku masyarakat dinilai dengan ' $u r u f$ yang didasari oleh wahyu iaitu nas al-Quran dan al-Sunnah serta beberapa perinsip syarak seperti maqasid dan qawa'id fiqh.

\section{Klasifikasi Mengikut Pendekatan Syarak}

Perubahan sosial berlaku secara langsung mengikut faktor-faktor yang mempengaruhi perubahan tersebut tanpa dikategorikan atau diklasifikasikan perubahan itu. Ia hanya dinilai mengikut kewajaran tindakan anggota masyarakat.

Keadaan ini tidak berlaku dalam 'uruf kerana nas al-Quran dan al-Sunnah telah meletakkan asas atau garis panduan untuk mengaplikasi 'uruf tersebut dalam aspek kehidupan. Ulama usul telah membahagikan 'uruf kepada uruf yang benar (sahih) atau 'uruf rosak (fasid). 'Uruf sahih ialah ' uruf yang boleh diambil kira dan sesuai diaplikasi kerana ketepatannya dengan kehendak syarak serta menjamin keharmonian masyarakat dan kelestarian hukum syarak. Dalam perubahan sosial, 'uruf fasid juga diambil kira selagi mana akal menghukum ianya wajar dan mampu diaplikasi. Ini berbeza konsepnya dalam pelaksanaan syariat Islam.

\section{Corak Perubahan}

Corak perubahan yang berlaku dalam perubahan sosial merujuk kepada realiti kegiatan masyarakat. Tingkah laku dan aktiviti masyarakat penentu kepada corak perubahan sosial. Manakala 'uruf dipengaruhi oleh perubahan sosial iaitu hasil daripada tingkah laku sosial masyarakat.Kedua-dua terminologi mempunyai persamaan dalam ukuran penentu corak perubahan dalam perubahan sosial dan 'uruf.

\section{Kesimpulan dan Dapatan}

Analisis dalam konteks terminologi ini dapat disimpulkan bahawa pemakaian terminologi perubahan sosial atau perubahan masyarakat diasaskan dalam ilmu sosiologi. Manakala perubahan budaya merupakan terma yang digunakan oleh ahli antropologi. Ketiga-tiga istilah ini membincangkan konsep atau prinsip yang sama menurut menurut Ramle Abdullah (temubual,1 Januari, 2015). Berpandukan penilaian dalam karya ini didapati asas perbincangan terminologi ini menurut perspektif syarak adalah dikategorikan sebagai 'uruf.

Perubahan sosial dalam aspek penjelasan kerangka faktor dan unsur-unsur perubahan sosial lebih terperinci berbanding dengan 'uruf yang menyebutnya secara umum, iaitu perkara yang menjadi kebiasaan manusia yang mencakupi perbuatan mahupun perkataan yang digunakan dalam sesuatu kelompok masyarakat. Hal ini dilihat sebagai umum dan ianya memerlukan penafsiran terperinci.

Dalam aspek pengaplikasian, 'uruf merupakan satu mekanisma yang menentukan kehidupan sosial masyarakat sama ada ianya sejajar dengan undang-undang syarak atau ianya mesti diabaikan pelaksanaannya kerana bertembung dengan maslahah dan hanya menjurus ke arah mafsadah. Setiap unsur-unsur perubahan sosial seperti struktur, sistem, organisasi, institusi, adat resam, budaya dan lain-lain lagi mempunyai perbincangan 'uruf di dalamnya. Manakala dalam konteks perubahan sosial ia tidak dikawal oleh mana-mana unsur dalam menilai ianya membawa kepada maslahah atau mafsadah dalam konteks pelaksanaan.

Elemen yang mengawal 'uruf ialah sumbersumber perundangan sharak iaitu al-Quran, al-Sunnah, al-Ijma', al-Qiyas dan lain-lain lagi sumber perundangan Islam. Manakala perubahan sosial, elemen yang mengawal dan memutuskan kewajaran pelaksanaannya berpusat kepada akal manusia semata-semata tanpa berteraskan kepada konsep maslahah 
dan mafsadah.Justeru, dalam situasi ini 'uruf bertindak sebagai mekanisma yang berfungsi menentu sesuatu perubahan sosial itu sama ada ia wajar diaplikasi dalam kehidupan sosial atau ianya semata-mata perubahan yang berlaku hasil kegiatan masyarakat yang wajar diabaikan, kerana ia didasari dan dipengaruhi oleh akal semata-mata. Selain itu perubahan tersebut mempunyai percanggahan dengan prinsip syarak dan sumber perundangannya.

Corak perubahan aktiviti hidup masyarakat dilihat dalam dua dimensi. Pertama, ianya diinterperetasi menurut kacamata atau perspektif individu atau ahli konvensional. Kedua ianya dinilai dari sudut perspektif Islam yang mendokong asas-asas syarak serta sumber perundangannya. Dalam situasi ini, antara perubahan sosial dan 'uruf, ianya terhasil dalam gelombang yang sama dan muncul dengan acuan atau pendekatan yang berbeza mengikut fahaman dan aliran pendokongnya.

Jelaslah di sini bahawa pengaplikasian 'uruf dalam menilai sesuatu perubahan sosial sama ada ia sejajar dengan kehendak syarak atau sebaliknya merupakan satu doktrin yang penting dalam memelihara kesepaduan hidup, yang boleh memandu aktiviti sosial dalam mencapai perinsip asas maqasid al-Shari'ah iaitu pemeliharaan nyawa, akal, maruah, keturunan dan harta. Selain itu, kestabilan hidup dalam masyarakat juga dapat dicapai melalui pemakaian doktrin 'uruf ini. Ini juga membuktikan bahawa pelaksanaan nilai murni Islam dalam semua aspek menjamin kelestarian kualiti hidup sosial yang meliputi aspek teknologi, ekonomi, politik, pendidikan, kekeluargaan, perindustrian, pembinaan dan sebagainya.

Justeru, dua disiplin ilmu ini sangat signifikan untuk dikombinasi dan diintegrasikan agar kualiti hidup dan pengimarahan bumi dapat direalisasikan secara aman dan harmoni sejajar dengan tuntutan dalam firman Allah s.w.t.:

Terjemahan: Dan (ingatlah) ketika Tuhanmu berfirman kepada Malaikat; "Sesungguhnya Aku hendak menjadikan seorang khalifah di bumi”. mereka bertanya (tentang hikmat ketetapan Tuhan itu dengan berkata): "Adakah Engkau (Ya Tuhan kami) hendak menjadikan di bumi itu orang yang akan membuat bencana dan menumpahkan darah (berbunuh-bunuhan), padahal kami sentiasa bertasbih dengan memujiMu dan mensucikanMu?". Tuhan berfirman: "Sesungguhnya Aku mengetahui akan apa yang kamu tidak mengetahuinya" (Quran, 2 30)

\section{Rujukan}

'Adli 'Ali Abu. (1997). Fi al-Taghayyur alIjtima'i (al-Iskandariyah: al-Maktab al-Jami' $i$ al-Hadis.

Abi Bakr Ahmad bin 'Ali al-Razi. (1994). alJasas, Ahkam al-Quran. Beirut: Dar al-Kutub al-Ilmiyyah.

Al-'Asqalani, Shihab al-Din Ahmad bin 'Ali bin Muhammad bin Hajar. (1995). Talkhis al-Habir fi Takhrij Ahadith al-Rafi'i al-Kabir, Tahqiq: Abu 'Asim Hasan bin 'Abbas bin Qutub, (t.t) Mu'assasah Qurtubah.

Al-'Asqalani, Shihab al-Din Ahmad bin 'Ali bin Muhammad bin Hajar. (1995). Talkhis al-Habir fi Takhrij Ahadith al-Rafi'i al-Kabir, Tahqiq: Abu 'Asim Hasan bin 'Abbas bin Qutub, (t.tp.: Mu’assasah Qurtubah.

Al-'Iwadi, Ahmad, al-Nizam. (t.t). al-Ijtima'i Fi al-Islam, (Jordan: Mu'assasah Ram littiknulujiyawa al-Kombiyuter.

Al-Ashqar, Muhammad Sulayman 'Abd Allah. (2012). al-Wadih fi Usul al-Fiqh, ('Amman: Dar al-Nafa'is.

Al-Bukhari, Abi 'Abdillah Muhammad bin Isma'il. (2000). Sahih al-Bukhari dalam Mausu' at al-Hadith al-Sharif al-Kutub al-Sittah, ed. Salih bin 'Abd al-'Aziz Al al-Shaykh, (alRiyad: Maktabah Dar al-Salam. 
Al-Bukhari, Abi 'Abdillah Muhammad bin Isma'il. (2000). Sahih al-Bukhari dalam Mausu'at al-Hadith al-Sharif: al-Kutub alSittah, ed. Salih bin 'Abd al-'Aziz Al al-Shaykh, al-Riyad: Maktabah Dar al-Salam.

Al-Durayni, Muhammad Fathi. (1997). alManahij al-Usuliyyah fi al-Ijtihad bi al-Ra'yi fi al-Tasyri' al-Islami, Bairut: Muassasah alRisalah, .

Al-Duri, Qahtan 'Abd al-Rahman. (2007) al'Aqidah al-Islamiyyah wa Mazahibuha, Jordan: Dar al-'Ulum.

Al-Farra', Al-Qadi Abi Ya'la Muhammad bin al-Husayn. (2006). al-Ahkam al-Sultaniyyah, Lubnan: Dar al-Kutub al-'Ilmiyyah.

Al-Mawardi, Abi al-Hasan 'Ali ibn Muhammad bin Habib. (1996). al-Ahkam al-Sultaniyyah, Amman: al-Maktab al-Islami.

Alpizar. (2008). "Islam dan Perubahan Sosial" Kertas Kerja Fakulti Usuluddin Universiti Islam Negeri Sultan Syarif Kasim Riau.

Al-Qardawi. (2008). Yusuf, Mujibat Taghayyur al-Fatwa Fi 'Asrina. Mesir: Dar al-Shuruq.

Al-Sa'di. (2003). 'Abd al-Malik Abd al-Rahman, Masa'il fi Fiqh al-Zakat wa Mustajiddatiha alMu'asirah: Dirasah Fiqhiyyah Muqaranah,. Jordan: Maktabah Zikra.

Al-Sabuni, Muhammad 'Ali, (t.t).Safwat alTafasir. Lubnan: Dar al-Qalam.

Al-Sayyid Sabiq.(1999). Fiqh al-Sunnah. Qaherah: Dar al-Fathi li al-I'lam al-'Arabi.

Al-Tanubi, Muhammad 'Umar. (1995). al-Taghayyur al-Ijtima'i, Iskandariyyah: Mansha'ah al-Ma'arif Bi al-Iskandariyyah.

Al-Zarqa', Mustafa Ahmad. (1998). al-Madkhal Ila Fiqhi al-‘Am. Damsyiq: Dar al-Qalam.
Al-Zuhayli, Muhammad. (1999). al-Qawa‘id al-Fiqhiyyah 'Ala al-Madhahib al-Hanafiwa al-Shafi‘i. Kuwait: Jami‘ah al-Kuwait.

Al-Zuhayli. (2004). Wahbah, Usul al-Fiqh alIslami, Damsyiq: Dar al-Fikr.

Amir Hasan Dawi. (2009). Sekolah dan Masyarakat. Perak: Quantum Books.

Ibn Al-Humam, Kamal al-Din Muhammad bin 'Abd al-Wahid al-Siwasi. (2003). Sharh Fath alQadir, Tahqiq: 'Abd al-Razaq Ghalib al-Mahdi. Lubnan: Dar al-Kutub al-'Ilmiyyah.

Ibnu 'Abidin, Muhammad Amin Afandi. (t.t.). Majmu'ah Rasail Ibnu 'Abidin, Beirut: Dar Ihya' al-Turath al-Arabi.

Ihsan Muhammad al-Hasan. (1999). Mawsu'ah 'Ilm al-Ijtima', Lubnan: al-Dar al-'Arabiyyah Li al-Mawsu'at.

Junaenah Sulehan. (2005). Masyarakat Perubahan dan Pembangunan. Bangi: Penerbit Universiti Kebangsaan Malaysia.

Kamus Dewan. (2007). Ed. ke-4, Kuala Lumpur: Dewan Bahasa Dan Pustaka.

Majmu'ah Khubara. (2010). 'Arab fi 'Ilmi alIjtima', al-Mawsu'ah al-'Arabiyyah li 'Ilmi alIjtima. Tunisia: al-Dar al-‘Arabiyyah li al-Kitab.

Mayshil Man. (1994). Mausu'ah al-'Ulum alIjtima'iyyah, terj. 'Adil Mukhtar al-Hawari dan Sa'ad 'Abd al-'Aziz Masluh. Beirut: Maktabah al-Fallah.

Muhammad Baltaji. (2007). Ijtihad Umar Bin Al-Khattab Dalam Penetapan Syariat Islam, terj. H. Abdul Rachman Saleh Siregar. Selangor: Berlian Publications Sdn.Bhd.

Muhammad Firdaus, N. H. (2002). Kesan Perubahan Sosial Terhadap Hukum Islam. Selangor: Thinkers Library Sdn. Bhd. 
Rohana, Y. (2006). Asas Sains Sosial. Kuala Lumpur: Dewan Bahasa dan Pustaka.

Shalabi, Muhammad Mustafa. (1986) Usul al-Fiqh al-Islami. Bairut: Dar al-Nahdah alArabiyyah.

Sidi Gazalba. (1976). Masyarakat Islam. Kuala Lumpur: Polygraphic Press Sdn.Bhd.

Wilbert, E. M. (1986). Perubahan Sosial, terj. Cheu Hock Tong. Kuala Lumpur: Dewan Bahasa dan Pustaka. 